\title{
Clinical Prognosis in BRAF-Mutated PTC
}

\section{revisão}

EFISIO PUXEDDU
SONIA MORETII

Department of Internal

Medicine and Center for

Thyroid Proteomic and Genomic

Research (EP, SM), University of

Perugia; Regional Oncology

Referral Center (EP), "Santa

Maria della Misericordia"

Hospital, Perugia, Italy.
Recebido em 07/02/07

Aceito em 10/02/07

\section{ABSTRACT}

BRAF mutation has recently emerged as a potential prognostic marker for papillary thyroid carcinoma (PTC) due to several studies suggesting that it may condition the development of tumors with aggressive behavior. A study of the phenotypes of thyroid follicular cell lines and transgenic mice characterized by targeted expression of $B R A F$ mutation indicates that, at variance with RET/PTC rearrangement, it induces or facilitates genomic instability and higher invasiveness and eventually deeper tumor de-differentiation and more significant suppression of apoptosis. An analysis of differential gene expression of PTCs harboring BRAF mutation versus PTCs characterized by other genetic alterations shows an important impairment of the expression of genes related to intra-thyroidal iodine metabolism machinery, up-regulation of Glut1 mRNA, methylation-induced gene silencing of tumor suppressor genes and up-regulation of pro-angiogenetic proteins such as VEGF. Correlation of BRAF mutation with PTC clinico-pathological features yields controversial results, with several studies showing the association with unfavourable clinico-pathological qualities, while others do not confirm the findings. This review will summarize the studies in favor of or in contrast with a role of BRAF mutation as a prognostic marker in PTC. We will also indicate what information we still need in order to routinely introduce this indicator in clinical practice. (Arq Bras Endocrinol Metab 2007;51/5:736-747)

Keywords: BRAF mutation; Papillary thyroid carcinoma; Prognostic stratification; Prognostic marker; lodine metabolism; ${ }^{131}{ }^{1}$ ablative treatment

\section{RESUMO}

\section{Prognóstico Clínico no CPT com Mutações BRAF.}

Mutações no BRAF surgiram recentemente como potenciais marcadores prognósticos do carcinoma papílifero de tiróide (CPT) graças a vários estudos que sugerem que ele possa condicionar o desenvolvimento de tumores com comportamento agressivo. Um estudo do fenótipo das células de linhagem folicular de tiróide em camundongos transgênicos caracterizados pela expressão direcionada de mutações $B R A F$, indicam, à semelhança dos rearranjos RET/PTC, que ele induz ou facilita a instabilidade genômica, a alta invasividade e, por fim, uma profunda desdiferenciação tumoral com supressão mais significativa da apoptose. Uma análise da expressão gênica diferencial do CPT associado com mutações BRAF versus o CPT caracterizado por outras alterações gênicas mostra uma redução importante da expressão dos genes relacionados com a maquinaria do metabolismo do iodo intratiroideano, aumento da regulação do mRNA do Glut-1, silenciamento gênico induzido por metilação dos genes supressores tumorais e aumento da regulação das proteínas pró-angiogênicas, como a VEGF. A correlação da mutação BRAF com os achados clínico-patológicos do CPT mostra resultados controversos, com vários estudos indicando associação com parâmetros clínicopatológicos desfavoráveis e outros não confirmando esses achados. Esta revisão sumariza os estudos a favor ou não do papel da mutação BRAF como um marcador prognóstico no CPT. Indicaremos, também, quais informações são ainda necessárias para a introdução rotineira deste indicador na prática clínica. (Arq Bras Endocrinol Metab 2007;51/5:736-747)

Descritores: Mutação BRAF; Carcinoma papilífero de tireóide; Estratificação prognóstica; Marcador prognóstico; Metabolismo de iodo; Terapia ablativa com ${ }^{131}$ | 
T HYROID CANCER IS THE most common malignancy of the endocrine system, representing approximately $1 \%$ of all malignancies in Western countries (1). Among human cancers, which combined together have shown a decrease in incidence over the last few years, thyroid cancer has the most rapidly increasing incidence rates in women, and the second most rapid in men, with an annual percentage change of approximately $5 \%$, making it the sixth most common cancer in women, similar to melanoma of the skin or ovarian cancer (2). Papillary thyroid carcinoma (PTC) is the most frequent thyroid cancer histotype, accounting alone for more than $80 \%$ of malignant neoplasms of the gland (1).

The overall survival rate at 10 years for PTC patients is very good, exceeding 90-95\% (3). However, $5-20 \%$ of patients will experience local or regional recurrences, and up to $10 \%$ will have distant metastases (3). Ultimately, some patients diagnosed at late stage and presenting with advanced disease are not curable. Indeed, effective therapies for patients with invasive or metastatic thyroid cancer, if the disease is not surgically resectable and does not concentrate radio-iodine, are still lacking (1).

In order to optimize management of affected patients, either as to extent of initial treatment or as to intensity of follow-up, a preliminary prognostic stratification is very useful. Until now, the prognostic indicators of recurrent disease and of death were the patient's age at diagnosis, the histologic features and extent of the tumor and the completeness of initial treatment (4-11).

Based on these clinical parameters, several staging systems for thyroid carcinoma were developed, among which the tumor-node-metastasis (TNM) system is the most widely used (12). The TNM systems allow us to stratify patients fairly well for the risk of death, but are less powerful to assess the risk of recurrence. Indeed, the latter does not depend only on tumor extent and on a rough age subdivision (more or less 45 years), but also on additional predisposing factors such as very young age ( $<$ than 16 years) $(13,14)$, some histological variants (such as the tall- or columnar-cell variants, the diffuse sclerosing variant, or poorly differentiated carcinomas) (15-17), clear signs of vascular invasion, incomplete surgery or lack of radioiodine uptake (18-24).

All these clinical and pathological factors are well-recognized risk factors for tumor recurrences in PTC cohorts. However, they are not precise as regards an individual patient's likelihood of tumor recurrence. Moreover, complete risk evaluation based on current pathological and clinical criteria is not possible until the initial treatment (surgery plus eventual 131I ablation) has been performed and the complete characteristics of the tumor become known.

Thus, in order to improve clinical management of PTC patients additional prognostic indicators are needed. Ideally, they should aid in increasing the certainty of the recurrence risk of each PTC patient and should allow an efficient stratification of the risk before initial treatment. These indicators should also guide the extent of the first surgery, the strength of additional treatments (131I ablation and TSH suppression) and the intensity of follow-up.

A major effort to improve the panel of thyroid cancer prognostic indicators has entailed the use of molecular profiling to characterize tumors (25). Such molecular studies of thyroid tumors began with single or relatively small groups of potentially prognostic markers and have progressed to micro-array analyses of thousands of genes in large numbers of tissue samples (25).

At the present time, one of the most promising achievements in this field is the recognition of $B R A F$ mutation as a potential prognostic marker for PTC (26).

This review will focus on the clinical prognosis of BRAF-mutated PTC, summarizing the recent advances regarding the definition of the prognostic role of $B R A F$ mutation in papillary thyroid carcinoma.

\section{BRAF MUTATIONS IN PTC}

$\mathrm{RAF}$ is a serine/threonine kinase, which, after activation by RAS-GTP, triggers sequential phosphorylation and activation of MEK and ERK (27). Three functional RAF isoforms have been described in humans, A-RAF, B-RAF or BRAF and C-RAF (also termed cRaf-1). Among these, BRAF, with its gene located on chromosome 7 , is the most potent activator of the MAPK pathway (28). Very recently, large-scale genomic screens have detected mutations of $B R A F$ in $66 \%$ of malignant melanomas and at a lower frequency in colorectal and ovarian cancers (29).

The importance of $B R A F$ mutation also in thyroid cancer was revealed by several studies, which showed the frequent occurrence of this genetic alteration in PTC, with a prevalence ranging from 29 to 83\% (mean 44\%) (26). A unique somatic T1799A transversion in exon 15 , resulting in a V600E amino acid substitution (BRAFV600E), has been detected in virtually all cases analyzed so far, with the exception of a K601E mutation found in some follicular variants of PTC (30,31), a G474R mutation, involving exon 11, 
found in one follicular variant of PTC (31), a deletion of 3 nucleotides between codons 600 and 601 resulting in the VK600-1E mutation found in 3 PTC metastatic lymph-nodes (32) and a solid variant of PTC (33), an insertion of 3 nucleotides at position 599 resulting in the V599Ins mutation, detected in a classic variant of PTC (34), and a gene rearrangement $A K A P 9-B R A F$ described in 4 radiation-associated PTCs (35). All these mutations have been shown, or are thought, to destabilize BRAF kinase inactive conformation and to induce an oncogenic constitutive activation of the enzyme (35-37).

$B R A F$ mutations occur more frequently than other known PTC genetic alterations such as RET (8-33\% of PTC) and NTRKI rearrangements (5-15\% of PTC) and RAS point mutations (0-21\% of PTC) (26). Interestingly, when these mutations have been simultaneously searched for, they have been shown to be mutually exclusive, accounting together for an initiating genetic event in about $70 \%$ of PTCs $(34,38-40)$. These data, indicating self-sufficiency of each genetic alteration in follicular cell transformation, represent genetic evidence for the constitutive activation of the RET/PTCRAS-BRAF signaling pathway in PTC (38) and for a key role of the MAP kinase cascade activation in the transformation of thyroid follicular cells, as confirmed by in vitro studies on thyroid cell lines $(41,42)$.

The demonstration that thyroid-targeted BRAFV600E transgenic mice develop thyroid tumors with PTC features (43) and the frequent detection of $B R A F$ mutations in papillary microcarcinomas (20-52\%) $(30,44-47)$, thought to be early precursors of PTC, have been interpreted as evidence for an initiator role of $B R A F$ mutations in PTC.

$B R A F$ mutations are present not only in PTC, but to a smaller extent also in poorly differentiated and anaplastic thyroid carcinoma, especially when a welldifferentiated PTC component containing the same mutation is detectable $(44,48-52)$.

In conclusion, $B R A F$ mutation appears to play a very prominent role in PTC tumor genesis. This perception prompted numerous studies aimed at disclosing the phenotype induced by $B R A F$ mutation in thyroid follicular cells and more generally in papillary thyroid carcinomas.

\section{IN VITRO STUDIES ON THE BIOLOGICAL EFFECTS OF BRAF CONSTITUTIVE ACTIVATION IN THE THYROID}

The study of the biological effects elicited by BRAF constitutive activation in the thyroid was approached in two ways: either by studying the phenotypic and genomic changes induced by the expression of $\mathrm{BRAFV}^{200 \mathrm{E}}$ in thyroid cell lines and in the thyroids of transgenic mice (table 1), or by analyzing differential gene expression in human PTC samples characterized by $B R A F$ mutation versus normal thyroid tissue or PTC samples harboring different genetic alterations (table 2).

Conditional expression of BRAFV600E in the well-differentiated rat thyroid cell line PCCL3 was shown to induce de-differentiation and to confer little growth advantage because of concomitant activation of DNA synthesis and apoptosis (53). Interestingly, these effects were similar to those elicited by the induction of RET/PTC expression in the same cell model (54). However, BRAFV600E, in contrast to RET/PTC, was also shown to facilitate the acquisition of secondary genetic events through induction of genomic instability (53). Similarly, comparison of the expression profiles of PCCL3 cells characterized by the conditional expression of BRAFV600E, RET/ PTC3, or RET/PTC3 with small interfering RNAmediated knockdown of BRAF, showed the existence of a gene cluster commonly regulated by RET/PTC3 and BRAFV600E and two gene clusters specifically activated by each of the two oncoproteins (55). BRAFinduced gene cluster included matrix metalloproteinase 3 (MMP3), MMP9 and MMP13. Accordingly, conditional expression of BRAFV600E was associated with markedly increased invasion into Matrigel, while conditional expression of RET/PTC did not activate this phenomenon (55). Very recently, the transient expression of BRAFV600E in PCCL3 cells was also shown to sharply impair both $\mathrm{Na}^{+} / \mathrm{I}^{-}$symporter (NIS) expression and targeting to the plasma membrane, indicating loss of differentiation and predicting deficit of NIS-mediated ${ }^{131}$ I uptake (56). Interestingly, this impairment was not totally dependent on the MEKERK pathway. Finally, acute BRAFV600E over-expression in thyroid cancer cells was shown to increase nuclear factor $\kappa \mathrm{B}(\mathrm{NF}-\kappa \mathrm{B})$ DNA-binding activity, resulting in up-regulation of anti-apoptotic proteins $\mathrm{c}^{-}$ IAP-1, c-IAP-2, and X-linked inhibitor of apoptosis, up-regulation of MMPl and MMP9 and cell invasion into Matrigel (57). In summary, these data indicate that the expression of $B R A F$ mutation compared with other genetic alterations confers a more aggressive phenotype to follicular cells, including the acquisition of genomic instability and invasiveness and eventually of deeper loss of differentiation and stronger apoptotic resistance. Accordingly, targeted expression of BRAFV600E in thyroid cells of transgenic mice induced 
Table 1. Specific phenotypic and genomic changes induced by the expression of BRAFV600E in thyroid cell lines and in the thyroids of transgenic mice (see text for details).

\begin{tabular}{|c|c|c|c|}
\hline INDUCED EFFECT & EXPERIMENTAL MODEL & INVOLVED MECHANISM & REFERENCES \\
\hline Genomic instability & $\begin{array}{l}\text { PCCL3 cells with BRAFV600E condi- } \\
\text { tional expression }\end{array}$ & Not explored & $\begin{array}{l}\text { Mistutake N et al. } \\
\text { (53) }\end{array}$ \\
\hline $\begin{array}{l}\text { Up-regulation of MMP3, MMP9, } \\
\text { and MMP13 expression }\end{array}$ & $\begin{array}{l}\text { PCCL3 cells with BRAFV600E condi- } \\
\text { tional expression } \\
\text { (Microarray analysis) }\end{array}$ & Not explored & Mesa C et al. (55) \\
\hline $\begin{array}{l}\text { Impairment of NIS expression } \\
\text { and targeting to the plasma } \\
\text { membrane }\end{array}$ & $\begin{array}{l}\text { PCCL3 transiently expressing } \\
\text { BRAFV600E }\end{array}$ & $\begin{array}{l}\text { Not totally dependent on the } \\
\text { MEK-ERK pathway }\end{array}$ & $\begin{array}{l}\text { Riesco-Eizaguirre } \\
\text { G et al. (56) }\end{array}$ \\
\hline $\begin{array}{l}\text { Up-regulation of MMP1 expres- } \\
\text { sion }\end{array}$ & $\begin{array}{l}\text { WRO cells with BRAFV600E condi- } \\
\text { tional expression and } \\
\text { WRO and KTC- } 3 \text { cells infected } \\
\text { with an adenovirus vector carry- } \\
\text { ing BRAFV600E }\end{array}$ & $\begin{array}{l}\text { Increased NF-кB DNA-binding } \\
\text { activity }\end{array}$ & Palona I et al. (57) \\
\hline $\begin{array}{l}\text { Up-regulation of MMP9 expres- } \\
\text { sion }\end{array}$ & $\begin{array}{l}\text { WRO cells with BRAFV600E condi- } \\
\text { tional expression and } \\
\text { KTC-3 cells infected with an aden- } \\
\text { ovirus vector carrying BRAFV600E }\end{array}$ & $\begin{array}{l}\text { Increased NF-кB DNA-binding } \\
\text { activity }\end{array}$ & Palona I et al. (57) \\
\hline \multirow[t]{2}{*}{ Increased Matrigel invasion } & $\begin{array}{l}\text { PCCL3 cells with BRAFV600E condi- } \\
\text { tional expression }\end{array}$ & Not explored & Mesa C et al. (55) \\
\hline & $\begin{array}{l}\text { WRO cells with BRAFV600E condi- } \\
\text { tional expression and } \\
\text { WRO, KTC- } 3 \text {, and NPA cells } \\
\text { infected with an adenovirus vec- } \\
\text { tor carrying BRAFV600E }\end{array}$ & $\begin{array}{l}\text { Increased NF-кB DNA-binding } \\
\text { activity }\end{array}$ & Palona I et al. (57) \\
\hline $\begin{array}{l}\text { Up-regulation of c-IAP-1, c-IAP-2, } \\
\text { and X-linked IAP }\end{array}$ & $\begin{array}{l}\text { WRO cells with BRAFV600E condi- } \\
\text { tional expression and } \\
\text { WRO and KTC- } 3 \text { cells infected } \\
\text { with an adenovirus vector carry- } \\
\text { ing BRAFV600E }\end{array}$ & $\begin{array}{l}\text { Increased NF-кB DNA-binding } \\
\text { activity }\end{array}$ & Palona I et al. (57) \\
\hline $\begin{array}{l}\text { Development of invasive PTCs } \\
\text { which transition to poorly differ- } \\
\text { entiated carcinomas }\end{array}$ & $\begin{array}{l}\text { Targeted expression of BRAFV600E } \\
\text { in thyroid cells of transgenic mice }\end{array}$ & Not explored & $\begin{array}{l}\text { Knauf JA et al. } \\
\text { (43) }\end{array}$ \\
\hline
\end{tabular}

MMP: metalloproteinase

IAP: inhibitor of apoptosis

the development of invasive PTCs, which transitioned to poorly differentiated carcinomas (43), while RET/PTCl and RET/PTC3 thyroid-targeted transgenic mice developed only differentiated tumors which did not show loss of differentiation unless crossed with p53\% animals (58-61).

Microarray studies conducted on human PTC samples, genotyped for BRAFV600E point mutation, RET/PTCI and RET/PTC3 rearrangement and point mutations of KRAS, HRAS and NRAS allowed detection of distinct expression profiles for the $B R A F$, $R E T / P T C$ and $R A S$ gene mutation groups (62). Differences were so specific that by using the 20 most significantly regulated genes in each subset, these simple classifiers were able to classify correctly the mutational status of all the tumors. These findings clearly indicate that mutational status is the principal determinant of gene expression variation within these tumors, predicting differences in phenotype and therapy-responsiveness between PTC genetic subsets. Accordingly, this study allowed the detection of a significant reduction of the TPO gene expression specifically in PTCs harboring the BRAF mutation, which was also confirmed at the protein level by immunohistochemistry. A similar result was also reported by another group that confirmed lower total TPO mRNA expression in PTCs bearing $B R A F$ mutations in contrast with those not characterized by the genetic alteration, although 
Table 2. Differential gene expression correlated to BRAF mutation in PTC tissue samples.

\begin{tabular}{|c|c|c|c|}
\hline Gene & Function & $\begin{array}{l}\text { Expression changes detected } \\
\text { in BRAFV600E PTC }\end{array}$ & References \\
\hline TPO & $\begin{array}{l}\text { Thyroperoxidase } \\
\text { Thyroid hormone biosynthesis: } \\
\text { lodine organification into } \\
\text { tyrosines of thyroglobulin } \\
\text { Coupling of tyrosil residues }\end{array}$ & $\begin{array}{l}\text { mRNA down-regulation } \\
\text { Reduced protein expression (IHC) } \\
\text { mRNA down-regulation }\end{array}$ & $\begin{array}{l}\text { Giordano TJ et al. (62) } \\
\text { Di Cristofaro J et al. (63) } \\
\text { Durante C \& Puxeddu E et al. } \\
\text { (unpublished observation) }\end{array}$ \\
\hline SLC5A8/AIT & $\begin{array}{l}\text { Apical lodine Trasporter } \\
\text { lodine transfer across the apical } \\
\text { membrane of the follicular cell }\end{array}$ & $\begin{array}{l}\text { Methylation-associated silencing } \\
\text { mRNA down-regulation }\end{array}$ & $\begin{array}{l}\text { Porra V et al. (64) } \\
\text { Hu S et al. (69) } \\
\text { Durante C \& Puxeddu E et al. } \\
\text { (unpublished observation) }\end{array}$ \\
\hline NIS & $\begin{array}{l}\mathrm{Na}^{+} / \mathrm{I}^{-} \text {symporter } \\
\text { lodine transfer from the extracel- } \\
\text { lular compartment inside thyroid } \\
\text { follicular cells }\end{array}$ & $\begin{array}{l}\text { Reduced protein expression (IHC) } \\
\text { and impaired targeting to the } \\
\text { membranes (IHC) } \\
\text { mRNA down-regulation }\end{array}$ & $\begin{array}{l}\text { Riesco-Eizaguirre G et al. (56) } \\
\text { Durante C \& Puxeddu E et al. } \\
\text { (unpublished observation) }\end{array}$ \\
\hline$T g$ & $\begin{array}{l}\text { Thyroglobulin } \\
\text { Thyroid hormone storage protein } \\
\text { and main constituent of colloid }\end{array}$ & mRNA down-regulation & $\begin{array}{l}\text { Durante C \& Puxeddu E et al. } \\
\text { (unpublished observation) }\end{array}$ \\
\hline Glut1 & $\begin{array}{l}\text { Glucose transporter } 1 \\
\text { Glucose transport from the extra- } \\
\text { cellular compartment inside thy- } \\
\text { roid follicular cells }\end{array}$ & mRNA up-regulation & $\begin{array}{l}\text { Durante C \& Puxeddu E et al. } \\
\text { (unpublished observation) }\end{array}$ \\
\hline VEGF & $\begin{array}{l}\text { Vascular-endothelial growth factor } \\
\text { Important growth factor involved } \\
\text { in blood vessel formation in nor- } \\
\text { mal and tumoral tissues }\end{array}$ & Increased protein expression (IHC) & Jo YS et al. (68) \\
\hline TIMP3 & $\begin{array}{l}\text { Inhibitor of metalloproteinase- } 3 \\
\text { Inhibits matrix metalloproteinases } \\
\text { activation }\end{array}$ & Methylation-associated silencing & Hu S et al. (69) \\
\hline$D A P K$ & $\begin{array}{l}\text { Death-associated protein kinase } \\
\text { Involved in apoptosis activation }\end{array}$ & Methylation-associated silencing & Hu S et al. (69) \\
\hline
\end{tabular}

IHC: Immunohistochemistry.

in this case the difference was not statistically significant (63). Because thyroperoxidase plays a pivotal role in iodine organification during thyroid hormone synthesis, these results suggest that $B R A F$ mutant tumors should display a lower iodine retention capacity.

Similarly, another study showed a statistically significant relationship between the methylation-associated silencing of the $S L C 5 A 8$ gene, coding for an apical iodine transporter (AIT), important to ensure a passive transfer of the halogen across the apical membrane of the follicular cell, and the T1799A point mutation of the BRAF gene in conventional PTCs (64). Moreover, a recent immunohistochemical study reported a significantly low NIS expression and impaired targeting to the membranes in $B R A F$ mutation-positive samples (56). Because NIS plays a pivotal role in thyroid iodine uptake, this finding suggests impairment of iodine transport from the extra-cellular compartment to the cytoplasm of the follicular cell in $B R A F$ mutant tumors.

Very recently, our group examined the expression of a panel of thyroid differentiation markers, including NIS, AIT-B, thyroglobulin ( Tg), TPO, TSH receptor (TSH-R), the transcription factor PAX8, and glucose transporter type 1 (Glutl), in 38 PTCs harboring BRAF mutation, and 28 PTCs with wild-type $B R A F$ (Durante C, Puxeddu E, Filetti S and Russo D, unpublished observation). Whereas mRNA levels of all thyroid-specific genes examined, except TSH-R, were reduced in PTCs versus normal thyroid tissues, $B R A F$ mutation-positive tumors presented significantly lower mRNA expression levels of NIS, AIT$\mathrm{B}, \mathrm{Tg}$, and TPO than $B R A F$-wild type ones. On the contrary, the two groups presented similar levels of TSH-R and PAX8 mRNA expression. Moreover, Glut- 1 transcript levels were increased in all PTCs, and 
additional significant increases were noted in $B R A F$ mutation positive tumors compared to the $B R A F$-wild type counterpart.

In the first instance, the gene expression results reported so far account for a significant impairment of intra-thyroidal iodine metabolism in $B R A F$ mutant tumors, suggesting that this subset of PTC is characterized by a lower responsiveness to radioiodine therapy due to defects in iodine uptake and retention. Secondly, the up-regulation of the glucose transporter Glut-1, indicative of an increased glucose metabolism, predicts visualization of $B R A F$ mutant tumors and their metastases by F-18-fluordeoxyglucose (18-FDG) positron emission tomography (PET). Intriguingly, these findings recapitulate the typical clinical features of less differentiated and more aggressive PTCs, which lose iodine responsiveness but gain 18-FDG metabolization capacity (65-67).

Finally, two further studies still in favor of the more aggressive biology of $B R A F$ mutant PTCs deserve to be mentioned. The first reports a significant up-regulation of vascular endothelial growth factor (VEGF) in $B R A F$ mutation positive PTCs compared with $B R A F$-wild type PTCs, and its strong positive correlation to larger tumor size and extra-thyroidal invasion and more advanced tumor stage (68). The latter analyzed promoter methylation-induced gene silencing of several recently identified tumor suppressor genes, including those for tissue inhibitor of metalloproteinase-3 (TIMP3), the above-mentioned SLC5A8/AIT, death-associated protein kinase $(\mathrm{DAPK})$ and retinoic acid receptor $\beta 2(\mathrm{RAR} \beta 2)$, in $B R A F$ mutation-positive and -negative PTC tumor samples (69). Methylation of TIMP3, SLC5A8/AIT and $D A P K$ was significantly associated with $B R A F$ mutation and with several aggressive features of PTC, including extra-thyroidal invasion, lymph node metastasis, multifocality and advanced tumor stage. The authors concluded that their data suggest that aberrant methylation and consequent silencing of the studied tumor suppressor genes may be an important step in $B R A F$ mutation-promoted tumorigenesis and aggressiveness of PTC.

In conclusion, all the presented data clearly indicate that expression of $B R A F$ mutation is associated with induction of a more aggressive phenotype of transformed follicular cells when compared to other genetic alterations. Thus, it is conceivable that also at the clinical level the presence of $B R A F$ mutation might be strongly associated with unfavorable clinicopathological features and outcomes. Surprisingly, this was not always the case in the series analyzed so far.

\section{CONTROVERSIES ON BRAF MUTATION PROGNOSTIC VALUE IN PTC}

In the last four years we have seen the publication of at least sixteen studies which correlated $B R A F$ mutation with PTC clinical features predictive of recurrence/persistence or death, including age, gender, tumor size, extra-thyroidal invasion, lymph node metastases, distant metastases, multifocality, and stage and/or with pathological characteristics, including histologic variants of PTC $(30,44-48,56,68,70-77)$. Six of these studies also correlated $B R A F$ mutation with disease recurrence $(47,56,70,75-77)$, while two specifically analyzed PTC microcarcinoma series $(46,47)$. Moreover, during the same period the literature was enriched with three studies specifically analyzing $B R A F$ mutation prevalence in PTC lymph node metastases $(32,78,79)$, with three studies exploring $B R A F$ mutation prevalence in anaplastic thyroid carcinomas (50-52), and with five studies searching for the prevalence of $B R A F$ mutation in radiation-induced or sporadic PTC of young subjects (80-84).

Table 3 summarizes the findings of the sixteen studies correlating BRAF mutation with PTC clinicopathological features.

In detail, four studies found a statistically significant association of $B R A F$ mutation with an older age at the time of diagnosis of PTC $(30,44,73,77)$. Of note, three of these studies included one hundred patients or more. In agreement, very recently at least five papers have reported a low prevalence of $B R A F$ mutation in PTCs diagnosed in childhood (80-84). The inter-studies discrepancy may be related to heterogeneity in age distribution of patients in the different cohorts. In detail, inclusion of pediatric PTC or of a young adult population, whose tumors are less frequently positive for $B R A F$ mutation, or of older patients, whose PTC are eventually more frequently positive for the genetic alteration, may contribute to increasing the divergences of ages between the $B R A F$ mutation positive and negative groups allowing the studies to reach statistically significant differences. Although older age is an unfavorable prognostic factor (85), a relationship between $B R A F$ mutation, older age, and higher clinical aggressiveness still needs to be established.

Two studies correlated $B R A F$ mutation with male gender $(71,75)$. The inconsistency of the observation, not detected by the other 13 studies that addressed this issue, and the elusive biological mechanism regulating such a gender preference, imply a possible patient selection bias. 
Table 3. Findings of the studies correlating BRAF mutation with PTC clinicopathological features.

\begin{tabular}{|c|c|c|c|c|c|c|c|c|}
\hline & $\begin{array}{c}\text { Sedliarou } \\
\text { et al. } \\
\text { (microPTC) } \\
(46)\end{array}$ & $\begin{array}{c}\text { Fugazzola } \\
\text { et al.** } \\
(70)\end{array}$ & $\begin{array}{c}\text { Xu } \\
\text { et al. } \\
(71)\end{array}$ & $\begin{array}{c}\text { Puxeddu } \\
\text { et al.** } \\
\text { (72) }\end{array}$ & $\begin{array}{c}\text { Kim } \\
\text { et al. } \\
\text { (microPTC) } \\
\text { (47) }\end{array}$ & $\begin{array}{c}\text { Riesco- } \\
\text { Eizaguirre } \\
\text { et al. } \\
\text { (56) }\end{array}$ & $\begin{array}{c}\text { Trovisco } \\
\text { et al. } \\
\text { (30) }\end{array}$ & $\begin{array}{c}\text { Adeniran } \\
\text { et al. } \\
\text { (73) }\end{array}$ \\
\hline BRAFV600E cases/total & $13 / 46$ & $18 / 47$ & $21 / 56$ & $24 / 57$ & $31 / 60$ & $28 / 67$ & 33/72 (69 patients) & $40 / 97$ \\
\hline Age & NS & NS & NS & NS & NS & NS & $<0.0001$ & $<0.05$ \\
\hline Male gender & NS & NS & 0.038 & NS & NS & NS & NS & NS \\
\hline Tumor size & - & NS & NS & NS & - & - & NS & NS \\
\hline Extrathyroidal invasion & NS & NS & NS & NS & NS & 0.003 & NS & NS \\
\hline Lymph node metastases & NS & NS & NS & NS & 0.06 & NS & NS & NS \\
\hline Distant metastasis & NS & - & - & - & - & NS & - & NS \\
\hline Multifocality & - & NS & - & NS & NS & NS & $0.04^{*}$ & - \\
\hline Stage & NS & & - & NS & NS*** & $0.01 * * *$ & - & $0.06 * * *$ \\
\hline I & NS & - & & & & - & & \\
\hline II & & NS & - & & & & - & \\
\hline III & & NS & - & & & & - & \\
\hline IV & & NS & - & & & & - & \\
\hline Recurrence & - & NS & - & - & NS & 0.02 & - & - \\
\hline \multicolumn{9}{|l|}{ PTC histologic variants } \\
\hline Classic papillary & NS & 0.02 & - & 0.038 & - & NS & - & $<0.05$ \\
\hline Tall cell variant & NS & NS & - & NS & - & 0.09 & - & NS \\
\hline Follicular variant & $0.018^{*}$ & NS & - & NS & - & $0.01 *$ & - & NS \\
\hline
\end{tabular}

Table 3. Continuation.

\begin{tabular}{|c|c|c|c|c|c|c|c|c|}
\hline & $\begin{array}{c}\text { Nikiforova } \\
\text { et al. (44) }\end{array}$ & $\begin{array}{c}\text { Liu } \\
\text { et al. (74) }\end{array}$ & $\begin{array}{l}\text { Trovisco } \\
\text { et al. (45) }\end{array}$ & $\begin{array}{c}\text { Namba } \\
\text { et al. (48) }\end{array}$ & $\begin{array}{c}\text { Jo } \\
\text { et al. (68) }\end{array}$ & $\begin{array}{c}\text { Kim } \\
\text { et al. (75) }\end{array}$ & $\begin{array}{c}\text { Xing } \\
\text { et al. (76) }\end{array}$ & $\begin{array}{c}\text { Fugazzola \& } \\
\text { Puxeddu } \\
\text { et al. (77) }\end{array}$ \\
\hline BRAFV600E cases/total & $38 / 104$ & $49 / 105$ & $45 / 124$ & $38 / 126$ & $102 / 161$ & $149 / 203$ & $107 / 219$ & $99 / 260$ \\
\hline Age & $<0.0001$ & NS & - & NS & NS & NS & NS & 0.01 \\
\hline Male gender & NS & NS & - & NS & NS & 0.006 & NS & NS \\
\hline Tumor size & NS & NS & - & NS & 0.01 & 0.006 & $0.09 *$ & NS \\
\hline Extrathyroidal invasion & 0.03 & NS & - & NS & 0.08 & 0.062 & $<0.001$ & NS \\
\hline Lymph node metastases & NS & NS & - & NS & NS & NS & 0.001 & NS \\
\hline Distant metastasis & NS & NS & - & 0.033 & NS & - & - & NS \\
\hline Multifocality & - & NS & - & - & - & NS & NS & NS \\
\hline Stage & & NS & - & 0.049 & NS & NS*** & $0.002 * * *$ & \\
\hline $10.003^{*}$ & & - & & & & & NS & \\
\hline II & NS & & - & & & & & NS \\
\hline III & 0.0006 & & - & & & & & NS \\
\hline IV & 0.03 & & - & & & & & NS \\
\hline Recurrence & - & - & - & - & - & 0.037 & 0.004 & NS \\
\hline \multicolumn{9}{|l|}{ PTC histologic variants } \\
\hline Classic papillary & 0.0004 & NS & - & - & - & - & $<0.001$ & 0.0001 \\
\hline Tall cell variant & 0.002 & NS & NS & - & - & - & $<0.001$ & NS \\
\hline Follicular variant & $<0.0001 *$ & NS & $<0.0001^{*}$ & - & - & - & $<0.001^{*}$ & $0.0007^{*}$ \\
\hline
\end{tabular}

* In favour of BRAFWT subgroup; **The patients from the two studies were pooled with others in the study by Fugazzola \& Puxeddu et al; *** I+II vs III+IV

NS: not statistically significant; - : not calculated

Tumor size was detected as being significantly increased in BRAF mutation-positive PTCs in two studies $(68,75)$ and significantly reduced in a third one (76). In all the other studies no statistically significant difference was detected between BRAF mutation-positive and -negative tumors. The conclusion may be that $B R A F$ mutation does not significantly influence tumor growth. However, considering other findings possibly correlating $B R A F$ mutation with higher aggressiveness or invasiveness, the conclusion may be broader: $B R A F$ mutation does not favor tumor growth, but under the same growth conditions may induce earlier activation of tumor invasiveness.

In agreement with the latter statement, three studies detected a significant correlation between $B R A F$ mutation and extrathyroidal invasion (44, 
$56,76)$, and two others found a correlation very close to statistical significance $(68,75)$. Of note, four of these studies had the largest case collection of the series. The remaining studies were unable to detect this association, including an Italian multicenter one, which enrolled 260 patients (77).

A significant correlation between $B R A F$ mutation and lymph node metastases was pinpointed only by one study (76). Another study, conducted on a small microcarcinoma cohort, found a correlation close to statistical significance (47). However, at least three other recently published papers support the possibility that $B R A F$ mutations, either clonally present in the primary tumor or de novo formed in the metastatic cells, play a pivotal role in papillary thyroid carcinoma cells seeding at the level of lymph nodes $(32,78,79)$. In detail, two of these studies showed a significantly higher prevalence of lymph node metastases in $B R A F$ mutation-positive tumors $(78,79)$, while all three produced proof of possible de novo BRAF mutation formation in PTC lymph node metastatic cells.

Only one study found a weak statistically significant correlation between $B R A F$ mutation and distant metastases $(\mathrm{p}=0.033)(48)$. In part this lack of correlation may be related to the low number of patients presenting with distant metastases in each study. Thus, the findings obtained so far should be considered inconclusive.

A correlation between $B R A F$ mutation and more advanced stage of the disease was clearly detectable in four studies $(44,56,48,76)$ and was close to statistical significance in a fifth $(73)$. Four of these studies included about one hundred or more patients. However, two of the three studies including more than two hundred patients, one from Korea (75) and one from Italy (77), were unable to confirm the correlation, although in the case of the Asian study this could be due to the selection of only low-risk cases.

Among the six studies that analyzed the correlation between $B R A F$ mutation and recurrence $(47,56,70,75-77)$, three documented this association $(56,75,76)$. Three of the six studies included less than 70 cases $(47,56,70)$. Among the three studies including a higher number of patients, only the North American (76) and the Korean (75) were characterized by the finding, while the multicenter Italian study (77) was not able to show any statistically significant difference in recurrence rate between $B R A F$ mutation positive and negative tumors. Interestingly, as mentioned above, the Korean study included only low-risk patients with conventional PTC. However, only in the North American study did the detected statistically significant correlation between $B R A F$ mutation and recurrence at univariate analysis remain significant on multivariate analysis, after adjusting for conventional clinico-pathological predictors of recurrence. Moreover, in this study BRAF mutation was also an independent predictor of recurrence in patients with stage I/II disease. Median follow-up periods were respectively 15 months for the North American study, 88 months for the Korean study and 72 months for the Italian study. Thus, the high recurrence rate of $B R A F$ mutation-positive PTC in the North American study may be ascribed to a high rate of early relapses of persistent disease. In this study, a sub-analysis of twenty recurrent PTC patients showed that recurrent disease was more extensive and needed more aggressive treatment (surgical and external radiation therapies) in the $B R A F$ mutation-positive patients than in the BRAF mutation-negative ones. In addition to radioiodine treatment, nine of $13(69 \%)$ recurrent patients with $B R A F$ mutation needed at least one additional surgery and/or external radiation therapy, whereas only one of seven (14\%) recurrent patients without the mutation needed additional surgery and no radiotherapy. Moreover, seven of thirteen (54\%) patients in the BRAF mutation-positive group versus none of seven $(0 \%)$ in the BRAF mutation-negative group lacked ${ }^{131}$ I avidity in their foci of recurrent tumor. Interestingly, these findings are confirmed by the third recent study from Spain, which detected a correlation between $B R A F$ mutation and recurrence on a smaller group of patients over a follow-up period of 36 months (56). Also in this study, the frequencies of recurrences with negative 131I whole body scan were higher in the $B R A F$ mutation-positive group $(6 / 9,66 \%)$ than in the BRAF-mutation negative group $(1 / 3,33 \%)$, predicting a worse outcome and indicating a less differentiated state in the BRAF mutation-positive PTC. All these clinical findings are consistent with the abovementioned gene expression data (see previous section), which consistently indicate a depression of the intra-thyroidal iodine metabolism machinery in $B R A F$ mutation-positive PTC.

Nine of the ten studies which analyzed correlation of $B R A F$ mutation with PTC histological variants found a significant association between the presence of the genetic alteration and a conventional PTC histology (papillary or mixed follicular-papillary growth pattern) and/or between the absence of the genetic alteration and a pure follicular variant histology $(30,44,46,56,70,72,73,76,77)$. Three studies, characterized by the inclusion of a significant number of PTCs of the tall cell variant, also found a significant 
association between $B R A F$ mutation and the tall cell variant histology $(44,56,76)$. Thus, it clearly appears that mutation of $B R A F$ drives the development of PTCs with a pure papillary or tall cell papillary phenotype. The tall cell variant of PTC is considered by many authors more aggressive and less differentiated than the other histological variants of the tumor $(17,18)$. The specific association of a BRAFK601E and BRAFG474R mutations with the follicular variant of PTC recently described by one group (30) has not been confirmed by any other study so far.

$B R A F$ mutation was also detected in a significant subset of undifferentiated thyroid carcinomas $(44,48-52)$ and in one study in 2 out of 16 poorly differentiated thyroid tumors (44). In most of these studies a noteworthy part of the $B R A F$ mutation-positive undifferentiated or poorly differentiated thyroid carcinomas had a recognizable papillary well-differentiated background component. Where both components were tested simultaneously for the mutation, a $100 \%$ concordance of the BRAF profile was shown.

These findings demonstrate that progression from papillary thyroid carcinoma to poorly differentiated and anaplastic carcinoma may be favored in many tumors by constitutive activation of $B R A F$. Moreover, together with the evidence that $B R A F$ mutation also occurs in microcarcinomas $(30,44-47)$, they suggest that this mutation, being an early event and probably insufficient alone for the fully aggressive phenotype, may predispose the tumor cell to acquisition of additional genetic alterations, which in turn activate more aggressive pathways and lead to de-differentiation. As seen in the previous section, biological evidence from thyroid cell line $(53,56)$ and transgenic mice experiments $(43)$ support these conclusions. It is noteworthy that a recent study showed that one subset of anaplastic thyroid carcinomas are derived from $B R A F$ mutation positive PTC due to the gain of a $p 53$ mutation (52). RET/PTC rearrangement seems to behave differently and to define a subset of papillary thyroid carcinomas lacking evidence of progression to poorly differentiated or undifferentiated tumor phenotype $(52,86)$.

\section{CONCLUSIONS AND FUTURE DIRECTIONS}

The perception coming from the described biological and clinical studies is that $B R A F$ mutation is an adverse prognostic indicator for PTC. However, its routine clinical application for prognostic stratification is hampered by the discrepant data coming from the correlation studies summarized in the previous section and by the paucity of robust supporting clinical evidence. Indeed, only the study by Xing et al. (76) is characterized by the identification of a statistically significant correlation, which consistently holds at multivariate analysis.

These discrepancies might be due either to the heterogeneity of the histological variants of PTC or to the age group analyzed or to the small number of studied cases or to genetic differences of the considered populations. However, another explanation should also be taken into account: the possibility that the conflict of the data is related to an important difference in the extent of disease at the moment the patients entered the studies, namely the moment of initial treatment. Geographical differences in the timelines of thyroid cancer diagnosis may play an important role in this. Indeed, countries characterized by an easily accessible and free health care system, by awareness of thyroid disease due to diffusion of endemic goiter, and by intense use of thyroid ultrasonography may have a higher number of incidental early thyroid carcinoma diagnoses. In this context PTCs may not have fully expressed their aggressive potential and may receive a more complete initial surgical treatment so that the clinical measurement of the higher biological aggressiveness of $B R A F$ mutationpositive cancers may not be possible, at least in the short term (maybe in the long term it will). The situation might be different in countries where the most frequently detected tumors are those which are recognized because they are clinically evident. These cases may represent cancers which have developed their aggressive potential and that may be less amenable to radical surgery, and, if characterized by $B R A F$ mutation, less responsive to radioiodine.

Well-designed prospective multicenter studies are needed in order to definitively clarify the role of $B R A F$ mutation as a useful clinical indicator of PTC aggressiveness. Preliminary evaluation of the necessary statistical power and data analysis separating clinically relevant tumors from incidental ones will be important issues. If these studies confirm $B R A F$ effectiveness in prognostic stratification of PTC patients, it is conceivable that in the future preoperative genotyping of thyroid fine needle aspirates (FNA) could alter the surgical approach and radioiodine treatment modalities, perhaps by mandating more aggressive lymph node dissection and by inducing the use of higher doses of 131I in BRAF mutation-positive PTC. Moreover, a $B R A F$ genotype may condition a more intense followup and eventually the use of particular image modalities, such as 18-FDG positron emission tomography, to search for tumor persistence or recurrences. 
In conclusion, BRAF mutation might become a novel informative prognostic marker, which can readily be detected in FNA cytological material and has the potential to improve risk stratification and recurrence prediction in patients affected by PTC, thus leading to better informed decisions about initial and long-term management. However, appropriately designed studies aimed at definitively verifying this possibility still need to be initiated.

\section{ACKNOWLEDGMENTS}

This work was supported by the "Fondazione Cassa di Risparmio di Perugia" and "Associazione Italiana per la Ricerca sul Cancro", which partially supported the research work in our laboratory.

We wish to thank Dr. Flavia Barbi and Dr. Maria Tavano for their precious collaboration.

We intended to cite all the significant studies in this field, but apologize for the possible, unintended omission of any relevant references.

\section{REFERENCES}

1. Sherman SI. Thyroid carcinoma. Lancet 2003;361:501-11.

2. Surveillance Research Program CSB Surveillance, Epidemiology and End Results (SEER) Program, November 2003 (Edn). National Cancer Institute, 2004

3. Mazzaferri EL. Thyroid carcinoma: papillary and follicular. In: Mazzaferri EL, Samaan N (eds). Endocrine tumors. Cambridge: Blackwell Scientific, 1993. pp. 278-333.

4. Mazzaferri EL, Jhiang SM. Long-term impact of initial surgical and medical therapy on papillary and follicular thyroid cancer. Am J Med 1994:97:418-28.

5. Hay ID, Bergstralh EJ, Goellner JR, Ebersold JR, Grant CS. Predicting outcome in papillary thyroid carcinoma: development of a reliable prognostic scoring system in a cohort of 1779 patients surgically treated at one institution during 1940 through 1989. Surgery 1993;114 1050-7.

6. Hay ID, Thompson GB, Grant CS, Bergstralh EJ, Dvorak CE, Gorman CA, et al. Papillary thyroid carcinoma managed at the Mayo Clinic during six decades (1940-1999): temporal trends in initial therapy and long-term outcome in 2444 consecutively treated patients. World J Surg 2002;8:879-85.

7. Byar DP, Green SB, Dor P, Williams ED, Colon J, van Gilse $\mathrm{HA}$, et al. A prognostic index for thyroid carcinoma. A study of the E.O.R.T.C. Thyroid Cancer Cooperative Group. Eur J Cancer 1979:15:1033-41.

8. Tenvall J, Biorklund A, Moller T, Ranstam J, Akerman M. Is the EORTC prognostic index of thyroid cancer valid in differentiated thyroid carcinoma? Retrospective multivariate analysis of differentiated thyroid carcinoma with long followup. Cancer 1986;57:1405-14.

9. Shaha AR, Loree TR, Shah JP. Prognostic factors and risk group analysis in follicular carcinoma of the thyroid. Surgery 1995; $118: 1131-6$.

10. Sherman SI, Brierley JD, Sperling M, Ain KB, Bigos ST, Cooper DS, et al. Prospective multicenter study of thyroid carcinoma treatment: initial analysis of staging and outcome. National Thyroid Cancer Treatment Cooperative Study Registry Group. Cancer 1998:83:1012-21.
11. Links TP, van Tol KM, Jager PL, Plukker JThM, Piers DA, Boezen HM, et al. Life expectancy in differentiated thyroid cancer: a novel approach to survival analysis. Endocr Relat Cancer 2005; $12: 272-80$

12. Greene FL, Page DL, Fleming ID, Fritz AG, Balch CM, Haller DG, et al. American Joint Committee on Cancer 2002 AJCC cancer staging manual. New York/Berlin/Heidelberg: Springer-Verlag, 2002.

13. Schlumberger M, De Vathaire F, Travagli JP, Vassal G, Lemerle J, Parmentier C, et al. Differentiated thyroid carcinoma in childhood: long-term follow-up of 72 patients. J Clin Endocrinol Metab 1987:65:1088-94.

14. Vassilopoulou-Sellin R, Klein MJ, Smith $T H$, Samaan NA, Frankenthaler RA, Goepfert $\mathrm{H}$, et al. Pulmonary metastases in children and young adults with differentiated thyroid cancer. Cancer 1993:71:1348-52.

15. Sakamoto A, Kasai N, Sugano H. Poorly differentiated carcinoma of the thyroid. A clinicopathologic entity for a high-risk group of papillary and follicular carcinomas. Cancer 1983:52:1849-55.

16. Wenig BM, Thompson LD, Adair CF, Shmookler B, Heffess CS. Thyroid papillary carcinoma of columnar cell type: a clinicopathologic study of 16 cases. Cancer 1998;82:740-53.

17. Prendiville S, Burman KD, Ringel MD, Shmookler BM, Deeb $\mathrm{ZE}$, Wolfe $\mathrm{K}$, et al. Tall cell variant: an aggressive form of papillary thyroid carcinoma. Otolaryngol Head Neck Surg 2000:122:352-7.

18. Akslen LA, LiVolsi VA. Prognostic significance of histologic grading compared with subclassification of papillary thyroid carcinoma. Cancer 2000;88:1902-8.

19. Tubiana M, Schlumberger M, Rougier $P$, Laplanche A, Benhamou $E$, Gardet $P$, et al. Long-term results and prognostic factors in patients with differentiated thyroid carcinoma. Cancer 1985:55:794-804.

20. Toubeau M, Touzery C, Arveux P, Chaplain G, Vaillant G, Berriolo $A$, et al. Predictive value for disease progression of serum thyroglobulin levels measured in the postoperative period and after 131 , ablation therapy in patients with differentiated thyroid cancer. J Nucl Med 2004;45:988-94.

21. Schlumberger M, Berg G, Cohen O, Duntas L, Jamar F, Jarzab B, et al. Follow-up of low-risk patients with differentiated thyroid carcinoma: a European perspective. Eur J Endocrinol 2004;150:105-12.

22. Rouxel A, Hejblum G, Bernier MO, Boelle PY, Menegaux F, Mansour G, et al. Prognostic factors associated with the survival of patients developing loco-regional recurrences of differentiated thyroid carcinomas. J Clin Endocrinol Metab 2004:89:5362-8.

23. Cailleux AF, Baudin E, Travagli JP, Ricard M, Schlumberger $M$. Is diagnostic iodine-131 scanning useful after total thyroid ablation for differentiated thyroid cancer? J Clin Endocrinol Metab 2000;85:175-8.

24. Bachelot A, Cailleux AF, Klain M, Baudin E, Ricard M, Bellon $\mathrm{N}$, et al. Relationship between tumor burden and serum thyroglobulin level in patients with papillary and follicular thyroid carcinoma. Thyroid 2002;12:707-11.

25. Weber F, Eng C. Gene-expression profiling in differentiated thyroid cancer - a viable strategy for the practice of genomic medicine? Future Oncol 2005;1:497-510.

26. Xing M. BRAF mutation in thyroid cancer. Endocr Relat Cancer 2005;12:245-62.

27. Kolch W. Meaningful relationships: the regulation of the Ras/Raf/MEK/ERK pathway by protein interactions. Biochem J 2000;351 Pt 2:289-305.

28. Mercer KE, Pritchard CA. Raf proteins and cancer: B-Raf is identified as a mutational target. Biochim Biophys Acta 2003; $1653: 25-40$.

29. Davies H, Bignell GR, Cox C, Stephens P, Edkins S, Clegg S, et al. Mutations of the BRAF gene in human cancer. Nature 2002;417:949-54.

30. Trovisco V, Soares P, Preto A, de Castro IV, Lima J, Castro P, et al. Type and prevalence of BRAF mutations are closely associated with papillary thyroid carcinoma histotype and patients' age but not with tumour aggressiveness. Virchows Arch 2005:446:589-95. 
31. Castro $P$, Rebocho AP, Soares RJ, Magalhães J, Roque L, Trovisco $V$, et al. PAX8-PPAR $\gamma$ rearrangement is frequently detected in the follicular variant of papillary thyroid carcinoma. J Clin Endocrinol Metab 2006;91:213-20.

32. Oler G, Ebina KN, Michaluart P Jr, Kimura ET, Cerutti J. Investigation of BRAF mutation in a series of papillary thyroid carcinoma and matched-lymph node metastasis reveals a new mutation in metastasis. Clin Endocrinol (Oxf) 2005;62:509-11.

33. Trovisco $V$, Soares $P$, Soares $R$, Magalhães J, Sa-Couto $P$ Sobrinho-Simões M. A new BRAF gene mutation detected in a case of a solid variant of papillary thyroid carcinoma. Hum Pathol 2005;36:694-7.

34. Carta C, Moretti S, Passeri L, Barbi F, Avenia N, Cavaliere A, et al. Genotyping of an Italian papillary thyroid carcinoma cohort revealed high prevalence of BRAF mutations, absence of RAS mutations and allowed the detection of a new mutation of BRAF oncoprotein (BRAF(V599Ins)). Clin Endocrinol (Oxf) 2006;64:105-9.

35. Ciampi $R$, Knauf JA, Kerler R, Gandhi M, Zhu Z, Nikiforova $\mathrm{MN}$, et al. Oncogenic AKAP9-BRAF fusion is a novel mechanism of MAPK pathway activation in thyroid cancer. $\mathbf{J}$ Clin Inves 2005; 115:94-101.

36. Wan PT, Garnett MJ, Roe SM, Lee S, Niculescu-Duvaz D, Good VM, et al; Cancer Genome Project. Mechanism of activation of the RAF-ERK signaling pathway by oncogenic mutations of B-RAF. Cell 2004;116:855-67.

37. Moretti S, Macchiarulo A, De Falco V, Avenia N, Barbi F, Carta $C$, et al. Biochemical and molecular characterization of the novel BRAF(V599Ins) mutation detected in a classic papillary thyroid carcinoma. Oncogene 2006;25:4235-40.

38. Kimura ET, Nikiforova MN, Zhu Z, Knauf JA, Nikiforov YE, Fagin JA. High prevalence of BRAF mutations in thyroid cancer: genetic evidence for constitutive activation of the RET/PTC-RAS-BRAF signaling pathway in papillary thyroid carcinoma. Cancer Res 2003;63:1454-7.

39. Soares P, Trovisco V, Rocha AS, Lima J, Castro P, Preto A, et al. BRAF mutations and RET/PTC rearrangements are alternative events in the etiopathogenesis of PTC. Oncogene 2003;22:4578-80.

40. Frattini M, Ferrario $C$, Bressan $P$, Balestra D, De Cecco L, Mondellini $P$, et al. Alternative mutations of BRAF, RET and NTRK1 are associated with similar but distinct gene expression patterns in papillary thyroid cancer. Oncogene 2004;23:7436-40.

41. Melillo RM, Castellone MD, Guarino V, De Falco V, Cirafici AM, Salvatore G, et al. The RET/PTC-RAS-BRAF linear signaling cascade mediates the motile and mitogenic phenotype of thyroid cancer cells. J Clin Invest 2005;115:1068-81.

42. Mitsutake N, Miyagishi M, Mitsutake S, Akeno N, Mesa C Jr, Knauf JA, et al. BRAF mediates RET/PTC-induced mitogen-activated protein kinase activation in thyroid cells: functional support for requirement of the RET/PTC-RAS-BRAF pathway in papillary thyroid carcinogenesis. Endocrinology 2006;147:1014-9.

43. Knauf JA, Ma X, Smith EP, Zhang L, Mitsutake N, Liao XH, et al. Targeted expression of BRAFV600E in thyroid cells of transgenic mice results in papillary thyroid cancers that undergo dedifferentiation. Cancer Res 2005;65:4238-45.

44. Nikiforova MN, Kimura ET, Gandhi M, Biddinger PW, Knauf JA, Basolo $F$, et al. BRAF mutations in thyroid tumors are restricted to papillary carcinomas and anaplastic or poorly differentiated carcinomas arising from papillary carcinomas. J Clin Endocrinol Metab 2003;88:5399-404.

45. Trovisco V, Vieira de Castro I, Soares P, Maximo V, Silva P, Magalhães J, et al. BRAF mutations are associated with some histological types of papillary thyroid carcinoma. J Pathol 2004;202:247-51.

46. Sedliarou I, Saenko V, Lantsov D, Rogounovitch T, Namba H, Abrosimov A, et al. The BRAFT1796A transversion is a prevalent mutational event in human thyroid microcarcinoma. Int J Oncol 2004;25:1729-35.

47. Kim TY, Kim WB, Song JY, Rhee YS, Gong G, Cho YM, et al. The BRAF mutation is not associated with poor prognostic factors in Korean patients with conventional papillary thyroid microcarcinoma. Clin Endocrinol (Oxf) 2005;63:588-93.
48. Namba H, Nakashima M, Hayashi T, Hayashida N, Maeda S, Rogounovitch $\mathrm{TI}$, et al. Clinical implication of hot spot BRAF mutation, V599E, in papillary thyroid cancers. J Clin Endocrinol Metab 2003;88:4393-7.

49. Xing M, Vasko V, Tallini G, Larin A, Wu G, Udelsman R, et al. BRAF T1796A transversion mutation in various thyroid neoplasms. J Clin Endocrinol Metab 2004;89:1365-8.

50. Soares P, Trovisco V, Rocha AS, Feijão T, Rebocho AP, Fonseca $E$, et al. BRAF mutations typical of papillary thyroid carcinoma are more frequently detected in undifferentiated than in insular and insular-like poorly differentiated carcinomas. Virchows Arch 2004;444:572-6.

51. Begum S, Rosenbaum E, Henrique R, Cohen Y, Sidransky D, Westra WH. BRAF mutations in anaplastic thyroid carcinoma: implications for tumor origin, diagnosis and treatment. Mod Pathol 2004;17:1359-63.

52. Quiros RM, Ding HG, Gattuso P, Prinz RA, Xu X. Evidence that one subset of anaplastic thyroid carcinomas are derived from papillary carcinomas due to BRAF and p53 mutations. Cancer 2005; 103:2261-8.

53. Mitsutake N, Knauf JA, Mitsutake S, Mesa C Jr, Zhang L, Fagin JA. Conditional BRAFV600E expression induces DNA synthesis, apoptosis, dedifferentiation, and chromosomal instability in thyroid PCCL3 cells. Cancer Res 2005;65:2465-73.

54. Wang J, Knauf JA, Basu S, Puxeddu E, Kuroda H, Santoro M, et al. Conditional expression of RET/PTC induces a weak oncogenic drive in thyroid PCCL3 cells and inhibits thyrotropin action at multiple levels. Mol Endocrinol 2003; 17:1425-36.

55. Mesa C Jr, Mirza M, Mitsutake N, Sartor M, Medvedovic M Tomlinson C, et al. Conditional activation of RET/PTC3 and BRAFV600E in thyroid cells is associated with gene expression profiles that predict a preferential role of BRAF in extracellular matrix remodeling. Cancer Res 2006;66:6521-9.

56. Riesco-Eizaguirre G, Gutierrez-Martinez P, Garcia-Cabezas MA, Nistal M, Santisteban P. The oncogene BRAFV600E is associated with a high risk of recurrence and less differentiated papillary thyroid carcinoma due to the impairment of $\mathrm{Na}^{+} / \mathrm{I}^{-}$ targeting to the membrane. Endocr Relat Cancer 2006; 13:257-69.

57. Palona I, Namba H, Mitsutake N, Starenki D, Podtcheko A, Sedliarou I, et al. BRAFV600E promotes invasiveness of thyroid cancer cells through nuclear factor $\kappa B$ activation. Endocrinology 2006;147:5699-707.

58. Powell DJ Jr, Russell J, Nibu K, Li G, Rhee E, Liao M, et al. The RET/PTC3 oncogene: metastatic solid-type papillary carcinomas in murine thyroids. Cancer Res 1998;58:5523-8.

59. Jhiang SM, Sagartz JE, Tong Q, Parker-Thornburg J, Capen CC, Cho JY, et al. Targeted expression of the ret/PTC1 oncogene induces papillary thyroid carcinomas. Endocrinology 1996;137:375-8.

60. La Perle KM, Jhiang SM, Capen CC. Loss of p53 promotes anaplasia and local invasion in ret/PTC1-induced thyroid carcinomas. Am J Pathol 2000;157:671-7.

61. Powell Jr DJ, Russell JP, Li G, Kuo BA, Fidanza V, Huebner K, et al. Altered gene expression in immunogenic poorly differentiated thyroid carcinomas from RET/PTC3p53-/- mice. Oncogene $2001 ; 20: 3235-46$.

62. Giordano TJ, Kuick R, Thomas DG, Misek DE, Vinco M, Sanders D, et al. Molecular classification of papillary thyroid carcinoma: distinct BRAF, RAS, and RET/PTC mutation-specific gene expression profiles discovered by DNA microarray analysis. Oncogene 2005;24:6646-56.

63. Di Cristofaro J, Silvy M, Lanteaume A, Marcy M, Carayon P, De Micco C. Expression of tpo mRNA in thyroid tumors: quantitative PCR analysis and correlation with alterations of ret, Braf, ras and pax8 genes. Endocr Relat Cancer 2006;13:485-95.

64. Porra V, Ferraro-Peyret C, Durand C, Selmi-Ruby S, Giroud H, Berger-Dutrieux N, et al. Silencing of the tumor suppressor gene SLC5A8 is associated with BRAF mutations in classical papillary thyroid carcinomas. J Clin Endocrinol Metab 2005;90:3028-35. 
65. Wang W, Macapinlac H, Larson SM, Yeh SD, Akhurst T, Finn $\mathrm{RD}$, et al. $18 \mathrm{~F}$-2-fluoro-2-deoxy-D-glucose positron emission tomography localizes residual thyroid cancer in patients with negative diagnostic 131| whole body scans and elevated serum thyroglobulin levels. J Clin Endocrinol Metab 1999:84:2291-302.

66. Helal BO, Merlet P, Toubert ME, Franc B, Schvartz C, Gauthier-Koelesnikov $\mathrm{H}$, et al. Clinical impact of $18 \mathrm{~F}-\mathrm{FDG}$ PET in thyroid carcinoma patients with elevated thyroglobulin levels and negative ${ }^{131}$ | scanning results after therapy. J Nucl Med 2001;42:1464-9.

67. Nahas Z, Goldenberg D, Fakhry C, Ewertz M, Zeiger M, Ladenson PW, et al. The role of positron emission tomography/ computed tomography in the management of recurrent papillary thyroid carcinoma. Laryngoscope 2005;115:237-43.

68. Jo YS, Li S, Song JH, Kwon KH, Lee JC, Rha SY, et al. Influence of the BRAFV600E mutation on expression of vascular endothelial growth factor in papillary thyroid cancer. J Clin Endocrinol Metab 2006;91:3667-70.

69. Hu S, Liu D, Tufano RP, Carson KA, Rosenbaum E, Cohen Y, et al. Association of aberrant methylation of tumor suppressor genes with tumor aggressiveness and BRAF mutation in papillary thyroid cancer. Int J Cancer 2006;119:2322-9.

70. Fugazzola L, Mannavola D, Cirello V, Vannucchi G, Muzza M, Vicentini $L$, et al. BRAF mutations in an Italian cohort of thyroid cancers. Clin Endocrinol (Oxf) 2004:61:239-43.

71. Xu X, Quiros RM, Gattuso P, Ain KB, Prinz RA. High prevalence of BRAF gene mutation in papillary thyroid carcinomas and thyroid tumor cell lines. Cancer Res 2003:63:4561-7.

72. Puxeddu E, Moretti S, Elisei R, Romei C, Pascucci R, Martinelli $M$, et al. BRAFV599e mutation is the leading genetic event in adult sporadic papillary thyroid carcinomas. J Clin Endocrinol Metab 2004:89:2414-20.

73. Adeniran AJ, Zhu Z, Gandhi M, Steward DL, Fidler JP, Giordano TJ, et al. Correlation between genetic alterations and microscopic features, clinical manifestations, and prognostic characteristics of thyroid papillary carcinomas. Am J Surg Pathol 2006;30:216-22.

74. Liu RT, Chen YJ, Chou FF, Li CL, Wu WL, Tsai PC, et al. No correlation between BRAFV600E mutation and clinicopathological features of papillary thyroid carcinomas in Taiwan. Clin Endocrinol (Oxf) 2005;63:461-6.

75. Kim TY, Kim WB, Rhee YS, Song JY, Kim JM, Gong G, et al. The BRAF mutation is useful for prediction of clinical recurrence in low-risk patients with conventional papillary thyroid carcinoma. Clin Endocrinol (Oxf) 2006;65:364-8.

76. Xing $M$, Westra WH, Tufano RP, Cohen $Y$, Rosenbaum E, Rhoden $\mathrm{KJ}$, et al. BRAF mutation predicts a poorer clinical prognosis for papillary thyroid cancer. J Clin Endocrinol Metab 2005:90:6373-9.

77. Fugazzola L, Puxeddu E, Avenia N, Romei C, Cirello V, Cavaliere $A$, et al. Correlation between B-RAFV600E mutation and clinico-pathologic parameters in papillary thyroid carcinoma: data from a multicentric Italian study and review of the literature. Endocr Relat Cancer 2006;13:455-64.
78. Vasko V, Hu S, Wu G, Xing JC, Larin A, Savchenko V, et al. High prevalence and possible de novo formation of BRAF mutation in metastasized papillary thyroid cancer in lymph nodes. J Clin Endocrinol Metab 2005;90:5265-9.

79. Kim J, Giuliano AE, Turner RR, Gaffney RE, Umetani N, Kitago $M$, et al. Lymphatic mapping establishes the role of BRAF gene mutation in papillary thyroid carcinoma. Ann Surg 2006;244:799-804.

80. Kumagai A, Namba H, Saenko VA, Ashizawa K, Ohtsuru A, Ito $M$, et al. Low frequency of BRAFT1796A mutations in childhood thyroid carcinomas. J Clin Endocrinol Metab 2004; 89:4280-4.

81. Lima J, Trovisco V, Soares $P$, Maximo V, Magalhães J, Salvatore $\mathrm{G}$, et al. BRAF mutations are not a major event in postChernobyl childhood thyroid carcinomas. J Clin Endocrinol Metab 2004;89:4267-71.

82. Penko K, Livezey J, Fenton C, Patel A, Nicholson D, Flora M, et al. BRAF mutations are uncommon in papillary thyroid cancer of young patients. Thyroid 2005;15:320-5.

83. Powell N, Jeremiah S, Morishita M, Dudley E, Bethel J, Bogdanova T, et al. Frequency of BRAFT1796A mutation in papillary thyroid carcinoma relates to age of patient at diagnosis and not to radiation exposure. J Pathol 2005;205:558-64.

84. Rosenbaum E, Hosler G, Zahurak M, Cohen Y, Sidransky D, Westra WH. Mutational activation of BRAF is not a major event in sporadic childhood papillary thyroid carcinoma. Mod Pathol 2005; 18:898-902.

85. Mazzaferri EL, Kloos RT. Clinical review 128: Current approaches to primary therapy for papillary and follicular thyroid cancer. J Clin Endocrinol Metab 2001;86:1447-63.

86. Tallini G, Santoro M, Helie M, Carlomagno F, Salvatore G, Chiappetta $G$, et al. RET/PTC oncogene activation defines a subset of papillary thyroid carcinomas lacking evidence of progression to poorly differentiated or undifferentiated tumor phenotypes. Clin Cancer Res 1998;4:287-94.

\section{Address for correspondence:}

Efisio Puxeddu

Dipartimento di Medicina Interna

Sezione MISEM

Via Enrico dal Pozzo

06126 Perugia, Italy

Fax: (39-075) 573-0855

E-mail: efisio@dimisem.med.unipg.it 